

\title{
Kanskje teste, ofte utrede, alltid veilede
}

LEDER

\section{BENEDICTE PAUS}

E-post: benedicte.paus@ous-hf.no Benedicte Paus er spesialist i medisinsk genetikk, overlege ved Oslo universitetssykehus og professor ved Universitetet i Oslo.

Forfatter har fylt ut ICMJE-skjemaet og oppgir ingen interessekonflikter.

Pasienter med alvorlig og mulig arvelig sykdom og deres slektninger kan ha nytte av genetisk utredning og veiledning, også når prediktiv gentesting ikke er aktuelt.

Ved mange sykdommer, som for eksempel kreft, hjerte- og karsykdom, Alzheimers sykdom, Parkinsons sykdom og amyotrofisk lateral sklerose (ALS), utgjør arvelige tilfeller en liten undergruppe. Det skilles mellom familiære og sporadiske sykdomstilfeller, der førstnevnte antas å ha mendelsk arvegang og sistnevnte multifaktoriell årsak. Primær diagnostikk beror ofte på kliniske diagnostiske kriterier. Hensikten med genetisk utredning er først og fremst å identifisere de arvelige tilfellene, og utredningen kan, foruten å bekrefte diagnosen, identifisere undergrupper med særskilte behov for medisinsk og tverrfaglig oppfølging. Ved arvelig sykdom har hver familie sin egen sykdomsgivende mutasjon. Familiens spesifikke mutasjon kan oftere enn tidligere gi informasjon om prognose og behandlingsmuligheter. Genetisk utredning er et skoleeksempel på persontilpasset medisin, definert som forebygging, diagnostikk, behandling og oppfølging tilpasset biologiske forhold hos den enkelte (1).

Kun når en sykdomsgivende mutasjon er identifisert hos pasienten, kan friske slektninger tilbys testing for mutasjonen for å få kunnskap om egen risiko. Før slik prediktiv gentesting er genetisk veiledning lovpålagt i Norge, slik det er i mange andre europeiske land $(2,3)$. Ved noen alvorlige, arvelige sykdommer der det verken finnes effektiv forebygging eller behandling, følger veiledningen en nøye utarbeidet prosedyre. Forskning viser at flertallet av friske som velger prediktiv gentesting etter slik veiledning, takler det godt - uavhengig av testresultatet (4).

Nakken og medarbeidere har undersøkt om klinikere i praksis følger internasjonale anbefalinger om genetisk utredning av pasienter som har amyotrofisk lateral sklerose (5). I retningslinjene anbefales detaljert familieanamnese hos alle pasienter og DNAundersøkelser kun i visse familiære tilfeller (6). Selv om undersøkelse av noen gener kan akselerere den diagnostiske prosessen og gi prognostisk informasjon, skal det ifølge retningslinjene ikke rekvireres DNA-undersøkelse ved sporadiske tilfeller med klassisk sykdom.

Den sistnevnte anbefalingen er problematisk. I studien fra Akershus universitetssykehus 
manglet familieopplysninger i journalen i $38 \%$ av tilfellene (5), noe som viser at anbefalingene om å innhente en detaljert familieanamnese ikke var fulgt. Selv om pasienten er det første kjente sykdomstilfellet i familien, er det ikke gitt at det er sporadisk. På grunn av redusert gjennomslagskraft (penetrans) ved amyotrofisk lateral sklerose kan arvelig sykdom "gå under radaren», især i små familier. Autosomalt dominant og X-bundet arvelig sykdom kan også skyldes nyoppståtte mutasjoner, som på samme måte som andre mutasjoner kan overføres til etterkommere. Først etter flere generasjoner, eller når det er utført genetiske undersøkelser, kan man anta at tilfellet var sporadisk. Selv om familieanamnese og samtykkebasert innhenting av opplysninger er en del av tilbudet ved medisinskgenetiske avdelinger, tyder norske og utenlandske studier på at nevrologer i liten grad henviser ALS-pasienter dit. Dette kan skyldes manglende kjennskap til genetikk og genetiske tjenester, eller legens opplevelse av etiske og psykologiske utfordringer $(5,7)$.

Anbefalingen om begrenset bruk av genetisk utredning av pasienter med amyotrofisk lateral sklerose er begrunnet blant annet med pasientens og slektningers rett til ikke å vite om sykdommen er arvelig (5). Det er uvanlig å bruke uttrykket «rett til ikke å vite» om utredning av syke. Uttrykket betegner vanligvis friske personers rett til å avstå fra prediktiv gentesting. I pasient- og brukerrettighetsloven står det riktignok at pasienter har rett til ikke å bli pådyttet informasjon som de ikke ønsker om sin sykdom (8), men også at de har rett til å få den informasjonen som er nødvendig for å få innsikt i sin helsetilstand og innholdet i helsehjelpen. Uten genetisk utredning og veiledning frarøves både pasient og slektninger så vel generell informasjon om risiko basert på arvegang eller empiriske tall som muligheten til å velge om de vil vite eller ikke vite i tilfeller der slektninger kan tilbys prediktiv testing.

De konservative retningslinjene for genetiske undersøkelser ved amyotrofisk lateral sklerose har vært utarbeidet av og diskutert i nevrologiske fagmiljøer, men problemstillingene er de samme ved andre sykdommer. Det finnes ikke belegg for at informasjon om genetisk heterogenitet eller redusert penetrans skulle medføre $ø \mathrm{kt}$ psykologisk belastning for den som blir veiledet. God forklaring til pasient og familie krever imidlertid spesiell kompetanse som finnes hos genetiske veiledere. Pasienter med amyotrofisk lateral sklerose og deres slektninger vil ha nytte av genetisk utredning og veiledning uavhengig av mulighet for, eller ønske om, prediktiv gentesting.

\section{LITTERATUR:}

1. Helsedirektoratet. Persontilpasset medisin. Nasjonal strategi for helsetjenesten. https://helsedirektoratet.no/legemidler/persontilpasset-medisin(2.7.2018).

2. Rantanen E, Hietala M, Kääriäinen H. Regulations and practices related to genetic counseling in 38 European Countries.

http://www.eurogentest.org/fileadmin/templates/eugt/pdf/Results_of_survey_1_WP_3-1_Deco6.pdf (2.7.2018).

3. LOV-2003-12-05-100. Lov om humanmedisinsk bruk av bioteknologi m.m. (bioteknologiloven). https://lovdata.no/dokument/NL/lov/2003-12-05-100 (2.7.2018).

4. Crozier S, Robertson N, Dale M. The psychological impact of predictive genetic testing for Huntington's disease: a systematic review of the literature. J Genet Couns 2015; 24: 29-39. [PubMed][CrossRef]

5. Nakken O, Sørum L, Holmøy T. Genetisk utredning ved amyotrofisk lateral sklerose. Tidsskr Nor Legeforen 2018; 138. doi: 10.4045/tidsskr.18.0193. [CrossRef]

6. Andersen PM, Abrahams S, Borasio GD et al. EFNS guidelines on the clinical management of amyotrophic lateral sclerosis (MALS)-revised report of an EFNS task force. Eur J Neurol 2012; 19:36o 75. [PubMed][CrossRef]

7. Vajda A, McLaughlin RL, Heverin M et al. Genetic testing in ALS: A survey of current practices. Neurology 2017; 88: 991 - 9. [PubMed][CrossRef] 
8. LOV-1999-07-02-63. Lov om pasient- og brukerrettigheter (pasient- og brukerrettighetsloven). https://lovdata.no/dokument/NL/lov/1999-07-02-63 (2.7.2018).

Publisert:3. september 2018. Tidsskr Nor Legeforen. DOI: 10.4045/tidsskr.18.0574

(C) Tidsskrift for Den norske legeforening 2020. Lastet ned fra tidsskriftet.no 